\title{
The Intervention of Physical Games in Teaching English Grammar to Secondary School Students: A Review with Special Reference to the Secondary School Pupil in Puducherry, India.
}

\author{
Smrutisikta Mishra ${ }^{1}$, Jeyasakthi $\mathrm{V}^{2^{*}}$, and Velmurugan $\mathrm{K}^{3}$ \\ ${ }^{1}$ Assistant Professor in Humanities (English), Department of Humanities, National Institute of Technology, Karaikal, India. \\ ${ }^{2 *}, 3$ Ph.D Research Scholars, Department of Humanities, National Institute of Technology, Karaikal, India. \\ *Corresponding Author \\ smruti@nitpy.ac.in,sakthi27in06@yahoo.com,ommvel23@gmail.com
}

\begin{abstract}
:
Language is the primary means of human communication and Grammar is a significant feature of it to be excelled with. The teaching of English Grammar has evolved through phases from Grammar Translation Method to Computer Assisted Language Learning and deductive and inductive methods. Though English teachers attempt various methods to teach grammar, children tend to play rather than sit tight in class. Thus, there are considerable recent studies involving various indoor and outdoor games to teach English Grammar effectively. This current paper aims to bring to light the importance and efficacy of involving physical games to teach grammar to secondary school children. Games make children physically active and mentally alert. Things learned through games are unconsciouslycaptured and never forgotten. This paper focuses on the advantages of involving physical games to teach grammar to highly active teenagers and track their gradual increase in optimism towards learning a second language.
\end{abstract}

Keywords:

English Pedagogy, Grammar, Preposition, Physical Games, Positive Attitude.

\section{Introduction:}

In multilingual countries like India, English has gained the honour of being the official language, library language, and many others. Learning English as a foreign language remained a challenging task not only for the second language learners but also for the non-native teachers. Principally, children possess a soaring potential to learn and acquire any foreign language than the other learners learning a new language after childhood (McLaughlin, 1984). Children are eminent for their natural language acquisition competence and they cannot be exposed to serious learning always (Dunn, 2016). Thus the instructor must be conscious to adjust and alter the approaches and methods of teaching Grammar to cater to the needs of the young learners. If children love games, then it has to be included in education with slight modifications in the pedagogic styles by efficient teachers. Games in education are gaining fame and importance in due course of time.

First language acquisition occurs within any child through spoken usage, and primarily by listening followed by imitation of vocal sounds, to be followed by reading and writing in later stages. This is the reason a child easily acquires its mother tongue. But, in the case of a second language, learners start writing alphabets at schools as the first stage which is ablunder hindering their language learning. Naturally, the English teachers feel the burden to complete the syllabus and simultaneously to make the children learn the foreign language fluently. A child, starting from infanthood loves to play, and mainly at the age of 12 to 15 , they play games following various rules. In their game land, they need to communicate the rules and regulations of games and score win and lose. This approving setting encourages participants to communicate fluently which is the ultimate goal of acquiring a language. This proves to be a wonderful platform for any language teacher to gain advantage and make the child use the target language grammatically and thereby unconsciously learn the second language through different types of games. This creates a positive learning atmosphere and an optimistic attitude towards the second language, and thereby removing the aversion and fear of learning a second language that naturally exists in the minds of non-native learners. Games help achieve their goals easily and make the learning enjoyable.

As Wadsworth, B. J. (1971)stated thatJean Piaget, a renowned psychologist had analyzedthat there are four stages of intellectual or cognitive-developmental for learners, these are: (1) the Sensorimotor starting from birth through 18-24 months. (2) Preoperational phase from Toddlerhood (18-24 months) to early childhood (age 7),(3) Concrete Operational stage comprises ages 7 to 12 , and(4) Formal operational stage would encompass from 
adolescence through adulthood.Scott \& H Lisbeth, (1992) observe that atthis stage,childrenretain a standpoint to distinguish between the real and unreal. They are highly inquisitive to ponder and pester with questions. They believe whatever they hear and expect reactions from the real world. They possess discreet likes and dislikes. The students interrupt teachers' activities in class and raise lots of questions. At this age, they are so friendly and ready to learn with their peers.

There are also some other remarkable works done on using games to teach language rules by Hamzah \& Dourado; Hartani; Luong; Nguyen;(2005) and Yolageldili \& Arikan(2011). Nguyen, after his investigative study, acknowledged that games are an imperative element as they impart practice and pleasure through learning. In a similar prospect, Hamza and Dourado accomplished research to study the effect of games in teaching tenses to learners. The result shows that the experimental group achieves more encouragement and thus teachers supported the use of games as an actual tool for teaching grammar. On the other hand, Yolageldili and Arikan(2011) performed research on the perception of English teachers on using games in grammar class. The outcome is, teachers, considered games as a successful tool to teach grammar, but they approved of not using games often in their classes. Luong (2009) also considered the use of games in grammar class with $6^{\text {th }}$-grade students from 3 schools. The results proved the improvement of oral and written abilities of students with the involvement of games in their learning atmosphere. Besides, Hartani (2012) researched using mime games to teach present continuous tense to $5^{\text {th }}$-grade students and finally, he found out that the experimental group, who studied with mime games excelled better when compared to the other without the game. He concluded confirming the efficiency of involving games in teaching grammar to young minds is as much fruitful.(Hajji \& Kim, 2019)

For a successful learning process to occur, the learner needs to employ more than one sensory organ in the process, and here comes the idea of Total Physical Response (TPR) of Dr. James J.Asher. In this theory, learners listen to the commands and do the action physically, which makes them familiar with the substance, andthereby unconsciously learns language structure. In other words, Grammar is not taught explicitly rather the learners physically respond to verbal input. This process mimics their mother tongue learning.

In TPR, children are permitted to observe, recognize, and comprehend things in a relaxed manner prior to reacting. It was considered a good method for teaching a new language to the students mainly because it reduces the stress level of the learning environment and makes learning enjoyable, and it replicates the child's learning of their mother tongue to expose students in the light of the language before imitating the same (Freeman, 2000).

According to Wikipedia, the TPR method is a perfect example of the Comprehension approach in language teaching. This is a constructive way to learn vocabulary and many other grammatical terms. Asherdeveloped TPR theory after his thorough observation of young learning their mother tongue. Asher hypothesized three observations namely, the first language is learned mainly by listening; language learning must engage the right hemisphere of the brain, and finally, there must not be any stress in language learning (Contributors to Wikimedia projects, 2003). TPR is not an end in itself but may be accompanied by other interesting methods like techniques and games.

\section{A Newer Approach to Teach Grammar:}

Teaching Grammar today has changed a lot from the past days. Language Learning has shifted its focus from a teacher-centered to a student-centered approach. Memorizing grammar rules and practicing grammatical structures made learning of grammar strenuous and boring. As students love to play a lot, games and related activities are to be included in the learning process to make them active learners rather than passive listeners and note-takers of grammatical rules. Varieties of teaching methods are to be employed by a teacher in a language learning atmosphere to retain the interest and thereby stimulate the creativity of the learners. A more specific way to retain the interest of the learners is to employ games as a method along with other activities of teaching a language, especially grammar.

Rinvolucri(1992)observed that Grammar is conceivably grave and significant in any language learning and it needs to beexplored with students' fullest of energy levels and the only best way to adhere so, is by focusing their energy through Games.Rinvolucri demonstrated that games are both interesting and informative at the same time making children not only to play but also to learn inside and outside the classroom mainly knowing their limits and under the guidance of their facilitator.This is the way that games support them to excel in grammar. A grammar teacher can train the young minds with the principle of known to the unknown and turn up the learning atmosphere child friendly, making all learn a particular concept at the same time and creating a "locomotive that pulls the grammar train along" (Rinvolucri, 1992).

According to the theory of Howard Gardner, humans possess eight types of intelligence, and handling a topic in school must be attempted through six altered methods toquench the diverse thirst of the learners in the classroom 
(Gardner, 2006). Whatsoever may be the multiplicity of activities provided, remaining inside four walls may turn off young learners sooner or later. Learning a language is not just learning a theoretical subject, rather it is learning to live a new life and a novel life cannot be bound to the four walls of the classroom. And therefore here comes the necessity of employing outdoor games to the zone of teaching a second language.

\section{Definition of a Game and its importance in Language Acquisition:}

Jones (1980) stated that, when one or more partners compete or cooperate to perform an interesting amusing activity with some set of rules, it can be addressed as a game. According to Rogers (1981) Games are aim-oriented, rules bound, competition-based which would have an end line to win and connects the learners. Gibbs (1981) addressed games as an activity cooperatively performed by competitors who are goal-oriented decision-makers following a set of rules. Games have also been defined as an activity that has a beginning and its end would be defined by the winner (Rixon, 1981). Games demand cooperation and competition within and among the teams of players. While in the game, players would communicate among themselves using both verbal and nonverbal signs. Verbal communication helps develop their competence in their target language and nonverbal guarantees joy and amusement (Rixon, 1981).

A Game is ablended mixture of rules, of many elements such as rules, oppositions, contests, recreation, and learning all at the same time (Hadfield, 2001; Lee \& Rowland Lee, 1991; and Greenall, 1990). Even if teaching a second language seems a harder task, teachers create games in various contexts which may be utilized for teaching language skills and grammatical items, and thereby language learning may interest the learners (Wright, Betteridge, \& Buckby, 2006).

\section{The Need for Games in Grammar Classes:}

Unsurprisingly, students love to play regardless of their grade level. Starting from childhood, everything seems to be played-with for children, at their homes, with pencil boxes, notebooks, computers, internet, mobile phones, etc. with everything, everywhere and every time, children love to play and enjoy except in the classroom. Even there they would play if allowed by teachers. Some use games as instructional methods but some teachers may not (Marzano, 2010).

To check the correlation between games and language learning, it is necessary to know the definition and characteristics of games. In the opinion of Hadfield (2001), a Game is an exciting pursuit of entertainment, which abides by some rules and goal-oriented,it must be considered as an essential component of the language curriculum and not just an amusing activity allocated just for games hours alone. It can be used at all stages of the learning starting from controlled to free drill, to assist in recalling, repetition drill, also as a diagnosing tool for teachers toassess the difficulty of the learners and provide them with appropriate remedial training.

Games do have an educational value than just a time-filling or a warm-up activity. Lee (1979), a top-notch author of Language teaching, penned that most of the language games enable learners to use the language as it is,rather than in its correct form. Adding to his view, he insisted that games must not be used just at a superficial level but at the central level to make the language learning program effective. Surprisingly, Lee's idea was also endorsed by RichardAmato (1988) who believed that games can lessen anxiety which makes the acquisition of input more likely (Sigurðardóttir, 2010).

Considering the definitions and opinions about games of various researchers, the importance of games had been viewed as being highly valued in teaching. Using games in the classroom, not only boost the learners to have enjoyment but mainly to learn their lesson proficiently. Further, teachers and language instructors acknowledge that games in language learning environments amuse learning and carry out learning tasks in an interesting manner. On the other hand, most other language instructors utilize games as time fillers and as a break from their monotonous grammar learning classes (S.M. Silvers as cited in Uberman, 1998). Silvers reasoned this as the ignorance of those teachers who believe that students must have been given instruction and practice in the target language before involving them in a game atmosphere of learning. Despite all the facts, in the intention of revealing the benefits of involving games in the grammar learning atmosphere, Chen (as cited in Petrovic, 2014) puts forth certain beneficial features as follows. Games are child-centered with learners in focus. It advances competence in language proficiency. It creates a healthy atmosphere for the usage of language. It motivates language learning, reduces tension, and integrates linguistic skills. Games encourage learners to use language spontaneously and improve creativity and develop a cooperative usage of the language. Games foster participatory attitudes of the learners (2014).

Thus it can be considered that games serve as a medium to entertain, encourage, teach, test, retest, reinforce, and enhance fluency all at the same time. Educators must also be careful not to misuse the games or let it be abused. 
Facilitators must be very careful in deciding what game to use for specific purposes when to employ the games, where to use certain games to whom should be the game used. It lies in the shoulders of the teachers to adhere to the responsibility of using the games as a successful teaching tool otherwise the total setup would be collapsed (Petrovic, 2014). Although conservative educationalists continuously object to the aforesaid attributes of games, they tend to accept the games as they relax the tedious learning of grammar rules and structure drills which may be tiresome they affirm.

English grammar is taught through numerous methods by various teachers. Some teach implicitly, while others in an explicit manner. There are plentiful reasons to employ games in the process of Grammar teaching. Primarily they are entertainment. Teachers can never make any students learn without their lively partaking and commitment to the learning course. Games help build a good bond among students to make them feel equal. Games create a healthy stimulating learning environment. Games also help a language userfluently practice the language in a real-life situation which would be the fundamental aim of acquiring a language. Adequate exposure is essential for students to acquire language competence was strongly underscored by Tomlinson and Masuhara (2009) In games, students take turns and play roles and are made to experience greater responsibilities which would, in turn, increase their confidence level to open up their minds and willingness to face life (Langran \& Purcell, 1994).

Human emotions are highly attached to expressions in the language. Thus, strong positive emotions such as happiness, suspense, surprise, amusement can encourage learners positively with language learning. Learners must be emotionally involved in language learning to excel in fluency. Introverts would be highly benefited through games. While playing, even a timid child would volunteerhimself in the easy atmosphere to participate in every activity and express himself, though not grammatically but fluently. Games activate them to actively involve and thereby achieve the goal of learning grammar without losing their interest. This can also be executed successfully by segregating the whole class into smaller groups and shuffling the shy ones with other students (Langran \& Purcell, 1994).

Games can be considered as an appropriate strategy for all age groups of students and it can also be utilized for whatsoever subjects to teach. It creates anencouraging atmosphere for young learners in a school environment (Sigurðardóttir, 2010). Through games, diversity in the school environment can be established feeding the diverse needs of the learners. Such merriment and favorable environment can bring about a healthy progression in the learning of the students (Lovísa, Laufey \& Samúel,2006).

Concisely, games would prove more productive if used frequently in the language class mainly for teaching grammar. It not only relaxes young minds but also energizes and helps them learn better and excel in every language skill well. Kamal and Youngkeun(2019)in their study involved various games to teach grammar in Moroccan high schools. The study investigated the stance of Moroccan English teachers for the use of games in teaching grammar. This study has been conducted to find out whether there is any coordination between the use of games and grammar learning. Significantly the study proved that the learners who studied through games enjoyed whereas the controlled group were bored. Teachers agreed that games encouraged and boosts the performance of the learners inside and outside the classrooms. Thus they concluded claiming that grammar games provided an authentic atmosphere to learn grammar spontaneously. Observations recorded were grammar classes with games filled with enthusiasm, enjoyment, and proved successful. Even the shy learners came out of their shells to learn and participate. These results echoed Hansen's (1994) and Riedel's (2008) allegation that through games even the timid child will get their role for expressing and participating with a cherished mind.(Hajji \& Kim, 2019)

\section{Use of Physical Games in Grammar Classes:}

As per a recent study, it was found that children have higher energy levels compared to well-trained endurance athletes. Young children have fatigue-resistant muscles and also a very high aerobic metabolism (Salem, 2018). Such a high energy level must be productively utilized for learning in schools through various dynamic activities and games so that it can be prevented from being misused or wasted in passive activities such as watching TV and being addicted to mobiles and computer games. Other than school hours, children couldn't play anywhere in today's hustle and bustle of life. Thus physical activities and games were minimized and students were addicted to cyber activities which may affect them physically and psychologically thereby threatening our future society. Lack of physical activity may cause various other physical problems. According to Piaget, children's play is a replica of society they live in and their playing is learning of societal rules and regulations indirectly, and thus decreased physical games will lead to a decrease in their learning of social skills (Cole, 2005).

This resulted in an increased interest in the use of physical games in teaching a language in general and grammar in 
particular. This can be checked through various websites providing game techniques and lesson plans, convenient to be utilized by teachers who may utilize them in their classes. Though there is an emerging interest in using physical games or other types of kinesthetic activities in language classrooms, it may seem very startling that very few experimental studies can be found using the term 'physical games. One such thoroughly reviewed past studiesrelated tophysical games and second language acquisition was written by Tomlinson and Masuhara (2009). Numerous doctrines supporting physical games and second language acquisition have been propagated in their papers. Students were to be occupied both resourcefully and cognitively in the language experience so that the learners can take full advantage of their exposure to language in use (Tomlinson and Masuhara, 2009).

Especially in physical games, where the students will be mobile and active, their psychological capacities and neural systems would be activated and stimulated, initiating students to learn and for better retention capacity (Tuan and Doan, 2010). Students need to attain an optimistic touch to achieve communicative proficiency (Tomlinson and Masuhara, 2009). Learners ought to feel free with the second language and with the ambiance. Students must also be psychologically involved in the learning process without affecting their self-respect. This is also mentioned by Arnoldasserting that optimisticimpact could promote priceless reinforcement for learning whereas pessimistic impact would shut off the intellect and hinders learning. For a language learner, an opportunity is needed to try his knowledge of the second language, and physical games provide such a free and encouraging atmosphere to test their suppositions and get feedback from their friends and facilitators (Tomlinson and Masuhara, 2009).

Though there may not be germane works in physical games and grammar, some earlier studies (Bush 2015; Paris and Yussof, 2013) have scrutinized different types of games and their usefulness in language acquisition. All their tests and studies proved that students were motivated by games than in droning classroom teaching.

Prihhartin (2018), in the work "Learning Grammar through Physical Games" applied physical games and found it to be more effective in teaching a new grammatical item to students. Games helped the students to realize their mistakes and correct them, clarify their doubts, elaborate ideas, and mainly help them to stay motivated and energized throughout the language class. The researcher optimistically boosts the educators to include physical games in their methods of teaching. Well-designed games not only encourage learners to remain engaged and optimistic but also provide a constructive ambiance to learn newer grammatical items and excel in linguistic competence.

\section{Using Physical Games to Teach Prepositions: Examples and Illustrations.}

Most English teachers know the fact that teaching Prepositions to second language learners that too young students would be a challenging task. To make them understand the appropriate usage of prepositions, teachers can employ a variety of gaming activities that too physical activities so that the learning would be permanent and more comprehensible. Using playground games to teach prepositions would be an inviting idea for the learners and they would be more motivated (Jahanshahi, 2017).

An instance of a physical game "Walk in a circle", where students would walk in a circle simultaneously following the instructions of the teacher through some actions at the same time, for instance, walk backward, walk forward, etc.(Sigurðardóttir, 2010). To make this game more fitting in a preposition teaching classroom the teacher needs to instruct in the target language for example, "everybody has to walk backward", "everybody walk forward lifting your hand" etc. similarly, "Leader says", can be a wonderful and apt example to teach prepositions to young learners. Here teacher can play as a Leader and command others, for example, "Leader says bend forward", "Leader says backward march", "Leader says hide below your table". "This sort of game can also be categorizedas Physical Games because of the fact that the Leader's orders are usually physical" (Sigurðardóttir, 2010).

Games are language learning activities and they are not restricted to the age of the learner. It is important to choose the variety of games according to the subject to be taught as well as appropriate to the age of the learners. Wright, Betteridge, and Buckby(1984), assumed that students in their early teens are more likely to be self-conscious and teachers must be more cautious to consider their introversion while choosing games and pairing them for activities. Even Though the game selection is important, the approach, role, and energy level of the teacher towards the selected activity is also equally important influencing the learning activity (Wright, Betteridge \& Buckby, 1984).

\section{Perception of Teachers towards Grammar Games in Puducherry India:}

\subsection{Design:}

This study has been designed as a need-based review study to explore the beliefs and habits of English Language 
Teachers'.The paper focuses on investigating the attitude and involvement of teachers of the secondary school of the Puducherry region (Southern India) towards using games in young learners’ English Grammar classes.

\subsection{Methodology Adopted:}

\subsubsection{Participants:}

In this study, questionnaires were formed and data were collected from40English teachers who have been teaching secondary school students for not less than five years. These teachers are educating young students of secondary schools in various Government Schools of Puducherry and Karaikal regions of India. Their prospect of using games in grammar classes to teach English as a second language has been observed and recorded through Teachers' Questionnaire.

\subsubsection{SamplesUsed:}

For this study, a Teachers' Questionnaire which comprises 15 closed questions was planned and distributed among the English Teachers. The statements were related to Grammar Teaching, including games in teaching and the use of games in their language classes. The questionnaire had the participants to respond every statement in a five-point Likert scale with notations as: from 1 to 5, where Strongly Agree $=1 \ldots$ to ...Strongly Disagree $=5$. This pattern helps to represent the teachers' opinions based on their experiences, attitude towards the effectiveness of using grammar games in their English classes.

\subsection{Findings:}

Abbreviations Used in Table in Likert Scale 1 to 5:

$($ Strongly agree $=\mathrm{SA}$, agree $=\mathrm{A}$, neutral $=\mathrm{N}$, disagree $=\mathrm{DA}$, and strongly disagree $=\mathrm{SD})$

\begin{tabular}{|c|c|c|c|c|c|c|}
\hline SL & Statements & SA $(\%)$ & $\mathbf{A}(\%)$ & $\mathbf{N}(\%)$ & $\mathrm{D}(\%)$ & SD $(\%)$ \\
\hline S1 & Grammar is an essential part of any language learning. & 26.7 & 60 & 6.7 & 6.7 & 0 \\
\hline $\mathrm{S} 2$ & $\begin{array}{l}\text { I know about language learning games and I use them to } \\
\text { teach Grammar in my English classes }\end{array}$ & 20 & 53.3 & 20 & 6.7 & 0 \\
\hline S3 & $\begin{array}{l}\text { A game relieves tension from the minds of second language } \\
\text { learners so I choose to include some interactive language } \\
\text { games to teach grammar. }\end{array}$ & 26.7 & 60 & 13.3 & 0 & 0 \\
\hline S4 & $\begin{array}{l}\text { Games support teachers to retain the interest and span of } \\
\text { attention of the students in any learning activity. }\end{array}$ & 33.3 & 46.7 & 6.7 & 6.7 & 6.7 \\
\hline S5 & $\begin{array}{l}\text { I use physical games every day as the best way to warm up } \\
\text { and boost learners physically and mentally to learn newer } \\
\text { concepts. }\end{array}$ & 33.3 & 26.7 & 33.3 & 0 & 6.7 \\
\hline S6 & $\begin{array}{l}\text { Games are more objective and good time-fillers in } \\
\text { Classrooms. }\end{array}$ & 20 & 46.7 & 20 & 13.3 & 0 \\
\hline S7 & I operate games as an assessment tool in my class. & 13.3 & 40 & 20 & 26.7 & 0 \\
\hline S8 & $\begin{array}{l}\text { Games help to turn a grammar class comprehensible and } \\
\text { effective. }\end{array}$ & 26.7 & 60 & 6.7 & 0 & 6.7 \\
\hline S9 & $\begin{array}{l}\text { Using grammar games in English classes enhances better } \\
\text { learning with delight at the same time, so it is interesting. }\end{array}$ & 40 & 40 & 20 & 0 & 0 \\
\hline S10 & $\begin{array}{l}\text { With games, students are confident to use the language } \\
\text { fluently without any inhibition of committing mistakes. }\end{array}$ & 33.3 & 53.3 & 13.3 & 0 & 0 \\
\hline S11 & $\begin{array}{l}\text { Games stimulate the children to be active in the grammar } \\
\text { class rather than being bored with tedious grammar rules. }\end{array}$ & 33.3 & 60 & 6.7 & 0 & 0 \\
\hline S12 & $\begin{array}{l}\text { Games can be employed in English classes to encourage } \\
\text { even the shy student to take part in every language-oriented } \\
\text { activity. }\end{array}$ & 40 & 40 & 13.3 & 6.7 & 0 \\
\hline S13 & $\begin{array}{l}\text { Learning grammar through games would help create more } \\
\text { chances to use English in real-life situations in a socially } \\
\text { acceptable manner. }\end{array}$ & 26.7 & 46.7 & 20 & 6.7 & 0 \\
\hline
\end{tabular}




\begin{tabular}{|c|c|c|c|c|c|c|}
\hline S14 & $\begin{array}{l}\text { Games simplifythe teachers' task and make grammar } \\
\text { learning better }\end{array}$ & 13.3 & 66.7 & 6.7 & 13.3 & 0 \\
\hline S15 & $\begin{array}{l}\text { A Game easily removes the fear of learning a second } \\
\text { language and encourages the learners in a positive way. So it } \\
\text { is a successful tool. }\end{array}$ & 26.7 & 60 & 13.3 & 0 & 0 \\
\hline
\end{tabular}

\section{Table 01:Questionnaire on use of Games for Teaching Grammar}

\subsection{Data Analysis:}

All the data collected from the participants through the questionnaire was analyzed. The data was tabulated and the percentages for each statement were observed as follows in a table. The observed data from the questionnaire would be convenient in assessing how English Teachers go along with using games in their Grammar classes.

From Table 01, it can be observed that, To the first statement, the majority of the teachers $(86 \%)$ agreed that grammar is an essential aspect of any language learning. The second response indicates that more than half of the teachers $(73.3 \%)$ know and practice games in their language teaching classrooms. From the third statement, it is clear that most of the teachers $(86.7 \%)$ approve of the fact that games relieve the minds of the learners and so games are to be included in English class. The fourth response proves that many teachers $(80 \%)$ use games to retain the interest of the learners in their grammar classes. From the fifth statement, it is clear that many teachers $(60 \%)$ are much willing to include games as a warm-up activity to boost children in their physical and psychological development. During the sixth observation, participants $(67.7 \%)$ agree with games as an objective tool to use in classroom teaching. $53 \%$ of teachers wish to utilize games as an assessment tool too is transparent through the seventh statement. Nearly $86.7 \%$ of teachers concur with the eighth statement that games help to turn grammar comprehensible. As a response to the ninth utterance, about $80 \%$ of teachers, support the use of games in a language class to make it interesting. As of the tenth statement, $86.6 \%$ of teachers' authenticate that games ensure to boost the confidence level of the learners. A Game activates every nerve of a child is evident from the eleventh statement reported by $93.3 \%$ of teachers. Introverts can be brought out of their shells by games is apparent through the assurance of $80 \%$ of the teachers in the twelfth utterance. English learning is for life and through games, is the easiest way is the claim of $73 \%$ of teachers in the thirteenth statement. The Majority of teachers (80\%) acknowledge that games can smoothen the learning of grammar better through the fourteenth statement. $86.7 \%$ of teachers agree to the fifteenth utterance that games waive off the fear of learning a new language and also they approve it as a successful tool.

\subsection{Results and Discussion:}

The following graph depicts the percentage of Teachers who have Agreed (A), Strongly agreed(SA), and the Averaged agreement(AV) to all the statements, which shows that majority of the teachers are using games to teach grammar in their classes, and find it to be an effective way of language learning.

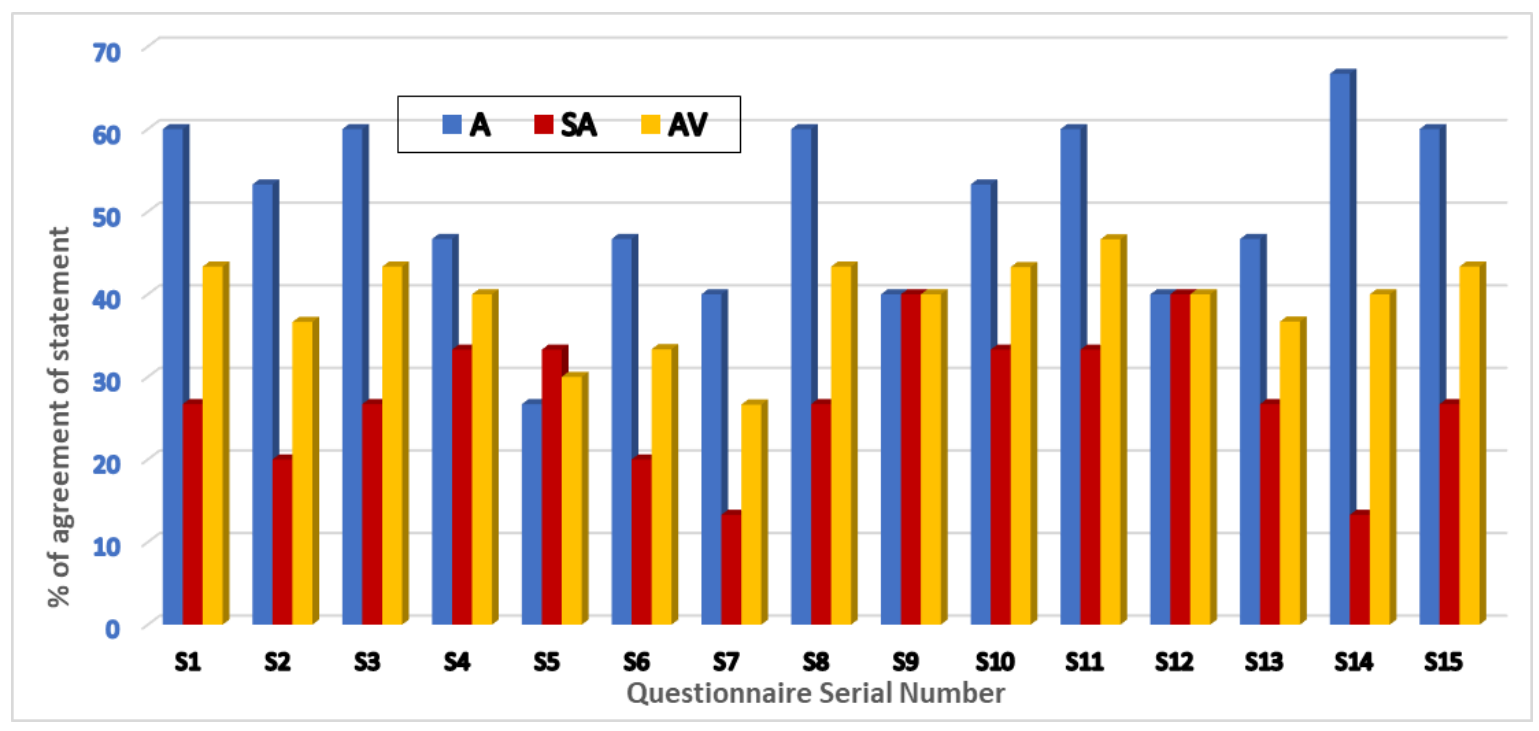

Fig 01: Teachers' Agreement to the Statements 
The following draft shows the percentage of popularity and strong agreement (SA) statement wise, where S-12 enjoys highly strong agreement among all teachers (40\% average) and S-07 is at $26.65 \%$, which shows that games are the best methods to employ to each student for efficient language learning.

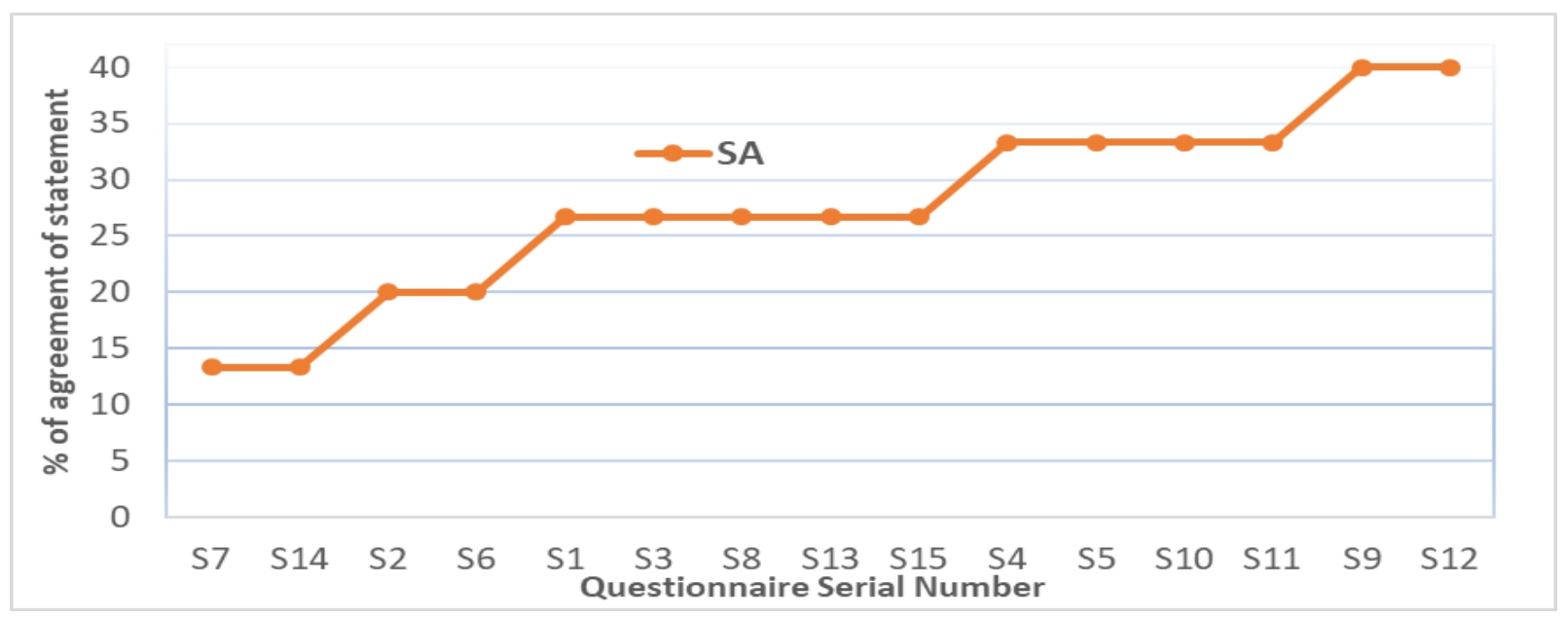

Fig 02: Ascending order of 'SA' average.

The following draft shows the percentage of popularity and agreement (A) statement wise,where S-14 enjoys highly strong agreement among all teachers (40\% average) and S-
05 is at $30 \%$, which shows that games are the best methods to employ to each student for efficient language learning, and it is also an easy pedagogic method.

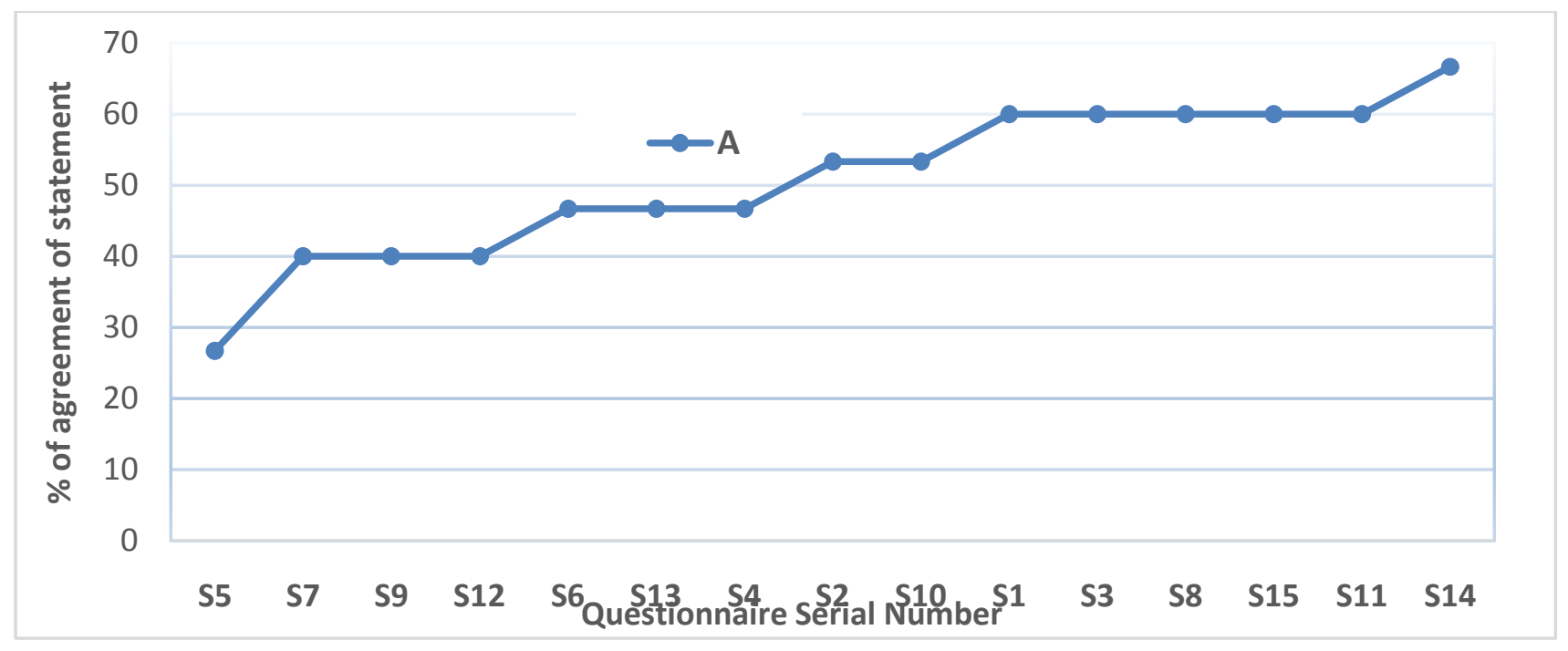

Fig 03: Ascending order of 'A' average.

\section{Conclusion and implications:}

After analyzing all the aforesaid data, and from the review of literature, it seems crystal clear that employing games in teaching grammar is fruitful and must be used in teaching methods for today's young, energeticand active learners. Games not only help to learn the language but also help the all-round development of the children. It boosts their learning and helps sustain their interest in their subjects taught. Games help teachers to identify the need and where the children have to be motivated so that necessary remedial measures can be adhered to by the teachers. Employing games in the classroom is not just relaxing the teachers and making the children play by themselves. But it lies in the responsibility of the teachers to be a part of the learners and guide the students throughout the learning - gaming process.

With games as a tool, teachers can reach out competently to a larger group of learners with ease. All subjects and all lessons may not be taught through games but still with students' active involvement, learning anything in a gaming mode would prove more amusing. Thus games must be used 
as a supplement to every teaching method to encourage student participation. Every child is unique and to be reached individually in an amicable manner to remove their aversion and inhibition towards learning. Also, games help students to feel mature with a feeling of self- respect. They learn not only the intended goal - the grammar but also to respect others' feelings, to adjust, to support peers, to cooperate, to forgive errors, develop leadership qualities, develop 'we' feelings and other moral values which may not be taught through any teaching methodologies. Physical games help them to grow as a wonderful individual who is physically, emotionally, linguistically, intellectually strong to face life ahead outside the school.

\section{References:}

1. Arnold, J. (n.d.). "Attention to Affect in Language Learning Anglistik". International Journal of English Studies, 22/1, 11-22.

2. Bakhsh, S. A. (2016). "Using Games as a Tool in Teaching Vocabulary to Young Learners". English Language Teaching, (Vol. 9, No. 7,). https://doi.org/10.5539/elt.v9n7p120.

3. Bush, J. C. (2015). "The Impact of Classroom Games on the Acquisition of Second Language Grammar". Language in Focus Journal, (Volume 1 / No.2). https://doi.org/10.1515/lifijsal-2015-0007

4. Chen, I. J. (2005). "Using Games to Promote Communicative Skills in Language Learning". The Internet TESL Journal, (Vol. XI, No. 2).

5. Cole, M., et al. (2005). The Development of Children. Macmillan.

6. Contributors to Wikimedia projects. (2003, July 4). Total physical response - Wikipedia. Retrieved May 22, 2020, from Wikipedia, the free encyclopedia website: https://en.wikipedia.org/wiki/Total_physical_response

7. Dunn, O. (2016). How young children learn English as another language.

8. Figueroa Flores, J. F. (2015). "Using Gamification to Enhance Second Language Learning”. Digital Education Review.

9. Freeman, D. L. (2000). Techniques and Principles in Language Teaching. Oxford University.

10. Gardner, H. (2006). The Development and Education of the Mind. https://doi.org/10.4324/9780203019689

11. Greenall, S. (1990). Language Games and Activities. Hulton Educational Publications. Ltd.

12. Hadfield, J. (2001). Beginners`Communication Games (4th ed). Addison Wesley Longman Ltd.

13. Hajji, K. A., \& Kim, Y. (2019). Teaching and Learning Grammar by Games In EFL Classrooms in Moroccan High Schools. International Journal of English and Education, (Volume:8, Issue:1).

14. Hamzah, Mohd. H. B., \& Emilia Dourado, J. (n.d.). Using Grammar Games in Teaching Grammar: A Case
Study in Smk Damai Jaya. Universiti Teknologi Malaysia Institutional Repository.

15. Hang, S. (2017). Using Games to Teach Young Children English Language. Psychology and Educational Science.

16. Hartani, A. L. (n.d.). The Effectiveness of Mime Game in Teaching English Grammar. TE YLIN $2: F r o m$ PolicytoClassroom.

17. Ho, P. \& A., \& Pham, A., Ngo\&Ho. (2018). The Effect of Using Total Physical Response (tpr) on EFL Young Learners' Vocabulary and Speaking Fluency.

18. Huyen, N. T. T., \& Nga, K. T. T. (2003). "Learning Vocabulary through Games".Asian EFL Journal Quarterly.

19. Jahanshahi, M. (2017). Teaching English Grammar with Special Reference to the Use of Prepositions at Secondary Level in AMU A Task Based Approach. Thesis.

20. Johns, A. M., \& Snow, M. A. (2006). Introduction to special issue: Academic English in secondary schools. Journal of English for Academic Purposes. https://doi.org/10.1016/j.jeap.2006.08.001

21. Langran, J., \& Purcell, S. (1994). Language Games and Activities. Netword 2: Teaching Languages to Adults. CILT, 20 .

22. Lee, W. R., \& Rowland Lee, W. (1991). Language Teaching Games and Contests. USA: Oxford University Press.

23. Long, M. H. (1990). Maturational Constraints on Language Development. Cognitive Science, (Volume 14, Issue 1).

24. Lovísa, K., Laufey, B., \& Samuel, L. (2006). Assessment of English language teaching in primary schools winter 2005-2006: prepared for the Ministry of Education. (Publications related to MMR issues).

25. Marzano, R. J. (2010, February). The Art and Science of Teaching / Using Games to Enhance Student Achievement. Retrieved May 15, 2020, from Http://Www.Ascd.Org/ website: http://www.ascd.org/publications/educational leadership/feb10/vol67/num05/Using-Games-toEnhance-Student-Achievement.aspx

26. McLaughlin, B. (1984). Second-Language Acquisition in Childhood. Psychology Press.

27. Paris, T. N. S. T. D., \& Yussof, R. L. (2013). "Use of Time Trap Board Game 'to Teach Grammar. ScienceDirect, Elsevier Ltd. https://doi.org/10.1016/j.sbspro.2013.11.042

28. Peters, A. (2015). Use of Games and Game-like Activities in Teaching English to Different Age Groups. World Scientific News 7.

29. Petrovic, E. P. (2014). Games in the Language Classroom-To Play Is to Learn. Malmö Högskola.

30. Prihhartini, S. (2018). Learning Grammar through Physical Games. Jurnal Pendidikan, (Volume 2 Issue 2, Jul-Dec 2018). https://doi.org/10.32533/02202. 
31. Riedel, C. (2008). Web 2.0: Helping Reinvent Education. Retrieved May 16, 2020, from Thejournal.Com website: ://thejournal.com/articles/2008/01/25/web-20-helpingreinvent-education.aspx

32. Rinvolucri, M. (1992). Grammar Games: Cognitive, Affective, and Drama Activities for EFL Students. Cambridge University Press.

33. Rixon, S. (1981). .How to Use Games in Language Teaching. MacMillan.

34. Salem, T. (2018, April 24). Children Have More Energy Than Endurance Athletes. Retrieved May 19, 2020, from Www.Usnews.Com website: https://www.usnews.com/news/nationalnews/articles/2018-04-24/study-children-have-moreenergy-than-well-trained-adults.

35. Scott, W. A., \& H Lisbeth, Y. (1992). Teaching English to Children. Longman.

36. Sigurðardóttir, S. D. (2010). The Use of Games in the Language Classroom.

37. Su, H., \& Zhang, L. (2020). Local grammars and discourse acts in academic writing: A case study of exemplification in Linguistics research articles. Journal of English for Academic Purposes, 43, 100805. https://doi.org/10.1016/j.jeap.2019.100805

38. Tomlinson, B., \& Masuhara, H. (2009). Playing to Learn: A Review of Physical Games in Second Language Acquisition. Simulation \& Gaming $X X(X)$. https://doi.org/10.1177/1046878109339969

39. Tuan, L. T., \& Doan, N. T. M. (2010). Teaching English Grammar Through Games. Studies in Literature and Language, (Vol. 1, No. 7, 2010, pp. 6175).

40. Uberman, A. (1998). The Use of Games for Vocabulary Presentation and Revision. Forum, (v36 n1 Jan-Mar 1998).

41. Wadsworth, B. J. (1971). Piaget's Theory of Cognitive Development. Addison-Wesley Longman Limited.

42. Wright, A., Betteridge, D., \& Buckby, M. (2006). Games for Language Learning (3rd ed.). Cambridge University Press.

43. Wu, X., Mauranen, A., \& Lei, L. (2020). Syntactic complexity in English as a lingua franca academic writing. Journal of English for Academic Purposes, 43, 100798. https://doi.org/10.1016/j.jeap.2019.100798

44. Yolageldili, G., \& Arikan, A. (2011). Effectiveness of Using Games in Teaching Grammar to Young Learners. Elementary Education Online. 